\title{
Efforts to Improve Community Economy Through Making Hand Crafts Based on Purun Plants
}

\author{
Julia Armiyanti Lestari ${ }^{1}$ Ersis Warmansyah Abbas ${ }^{1}$ Mutiani $^{1}$ Jumriani $^{1 *}$ Syaharuddin ${ }^{1}$ \\ ${ }^{1}$ Social Studies Education, Faculty of Teacher Training and Education, Lambung Mangkurat University, Banjarmasin, \\ Indonesia \\ ${ }^{*}$ Corresponding author. Email: jumriani@ulm.ac.id
}

\begin{abstract}
Poverty is a problem that must be the government's attention. The problem of poverty is closely related to the people's economy. Sustainable community economic development by prioritizing the principle of welfare should be done to overcome social problems. One of the patterns of developing community economic activities is by utilizing natural resources as part of economic activities. This article aims to describe sustainable community empowerment through making handicrafts made from purun plants in Palam Village, Cempaka District, Banjarbaru City. A qualitative approach is used in this study. The data analysis technique is done by interview, observation and documentation. Data analysis was performed by data reduction, data presentation and drawing conclusions. In order to maintain the validity of the data, checking was carried out with triangulation of sources, time and techniques as well as extension of observations. The results of the study describe that purun plants can be developed into various products that have sale value through a series of community economic activities. The craftsmen's creativity and government support play an important role for the sustainable development of the purun craftsmen's economic activities.
\end{abstract}

Keywords: Community, economic, hand crafts, purun plants

\section{INTRODUCTION}

Sustainable Development Goals are a commitment in every country. There are three goals in this. One of them is to alleviate poverty with the principle of showing sustainable development with a balance in three fields, namely environmental, social and economic [1].

Indonesia as a country that is in line with and committed to the success of implementing the Sustainable Development Goals in poverty alleviation through economic activities with the principle of creating prosperity for the community. As the data shows that the poverty rate in Indonesia is based on the official statistical news No. 56/07 / Th. XXII, 15 July 2019 per period March 2019 shows a decrease in numbers compared to March to September 2018. March 2018 shows the poverty rate in Indonesia per million people and the percentage of poor people as $25.95(9.82 \%)$ and September 2018 as many as 25, 67 (9.66\%) until March 2019 as many as $25.14(9.41 \%)$. This indicates a decrease of $0.25 \%$ points. Starting from March 2017 to March 2019 there has been a decrease in the poverty rate in Indonesia. Based on data from the urban poor in September 2018, it showed a percentage of $6.89 \%$, decreased in March 2019 to $6.69 \%$. Meanwhile, data on the rural poor shows that in September 2018 the percentage was $13.10 \%$, down to $12.85 \%$ in March 2019. The reduction in the poverty rate is inseparable from various efforts which of course can be seen from the point of view and the causes. The efforts made do not only come from one direction from the government, but also from the community itself.
Poverty is often measured by the income level of a household, namely doing business, working and obtaining from ownership of assets [2]. This shows that there must be human efforts in the form of various economic activities. Economic activity is a series of human efforts by utilizing existing resources to meet needs. Basic human needs are centered on personal, interpersonal and social systems [3]. Economic activities are simply carried out to fulfill needs and achieve economic growth towards social welfare.

Along with the continued promotion of economic growth, the abundance of natural resources has been processed and utilized, especially in the resources which are used as material supplies (stock resources). Humans as subjects in the social system must be able to determine the steps and utilize other alternative resources. Humans play a role as an important input in economic growth. Seeing opportunities, carrying capacity and environmental potential, increasing creativity without neglecting the aspects of profit in economic value. It is also related to decision making in fulfilling needs that should weigh opportunities versus risks to produce potential benefits in the future [2], [4], [5].

The development of the creative economy in the form of handicraft businesses is one thing that can be used as part of the economic activities of the community, which contributes to additional employment opportunities. As each region has regional characteristics and various potential resources. By comparison in Malaysia handicraft development is given proper recognition as a sector for eradicating poverty, especially among the rural population. The plan is to revitalize the cottage industry which involves 
the community as the main business actor [6]. Therefore, the presence of handicrafts as one of the economic sectors is in line with the principles of economic welfare based on social, economy and existing environmental potentials [7]. In Banjarbaru City, handicraft businesses have also been developed by utilizing purun plants as a basic material. Purun plants are plants that live freely or wildly in tidal swamps with acid sulfate content. Based on these distinctive characteristics, purun is often found in waterlogged swamps, at an altitude of $0-1,350 \mathrm{~m}$ above sea level and is commonly found in rice fields. Soil conditions that support the growth of purun are clay or humus with a $\mathrm{pH}$ of $6.9-7.3$, with a high acid content [8]. These purun plants are made into various handicrafts which are the result of woven craftsmen. On the basis of this, this article aims to describe the efforts to improve the community's sustainable economy through the economic activities of the community making handicrafts made from purun plants.

\section{METHODS}

This study used a qualitative approach with descriptive methods. The research was conducted in Purun Village, which is located in Palam Village, Cempaka District, Banjarbaru City. Data collection was carried out by interviewing, observation and documentation techniques. Research informants consisted of several parties, namely purun craftsmen, government and academics. The informants are as follows:

Table 1 Research Informant

\begin{tabular}{|c|c|c|}
\hline \multicolumn{3}{|c|}{ Category } \\
\hline Craftsmen & Government & Academic \\
\hline 1. Salasiah & 1. Katimin & 1. Dewi \\
\hline 2. Siti Mariana & 2. Muhammad Agus Adrian & 2. Akhmad Munaya Rahman \\
\hline 3. Rahmah & 3. Dhiah Tri Widhiningsih & 3. Felicitas Nella \\
\hline 4. Saiful & 4. Nadjmi Adhani & 4. Kabul \\
\hline 5. Amin & 5. Darmawan Jaya & 5. Muhammad Adithya Hidayat Putra \\
\hline 6. Maimunah & $\begin{array}{l}\text { 6. Rizla Syahrianoor Mahampang } \\
\text { 7. Hery Isdaryoko }\end{array}$ & 6. Hasanah \\
\hline
\end{tabular}

Source: Processed Data, 2019

Interview activities were carried out directly to informants using a recording aid. The results of the recorded interviews were then made into word-for-word interview transcripts. To obtain valid data, the results of interviews from one informant were cross-checked with the results of interviews with other informants. Researchers are involved in the activities of the craftsmen together with the activities of the purun craftsmen. The obstacle experienced by researchers in the observation stage is the determination of the time of observation which must adjust to the craftsmen's activities while the craftsmen's activities are difficult to predict, because they are timeless, they can be carried out at any time by the craftsmen so that the researcher encounters the same activity several times on several observations.

Data analysis was carried out following the pattern of Miles and Huberman which began with data reduction, data presentation, then verification [9]-[11]. The initial step of data analysis was carried out by selecting data that was relevant to the research focus, then presented it in a narrative form, until it reached a conclusion. In the process of analyzing data until it reaches the verification stage, researchers continue to test the validity of the data.

\section{RESULTS AND DISCUSSION}

Purun webbing is the result of hand craftsmanship. As a work, handicraft woven is a product that is produced full of beauty values from processing raw materials accompanied by skill and tenacity [12]. Crafts themselves are defined as items made by hand, often using simple tools, and generally of an artistic or traditional nature [12]. Weaving is an activity that has become a routine that has been carried out from old age to young people. The handicrafts represent local and indigenous traditions, they also symbolize the places, the experiences they have had [13], [14].

Wicker crafts are almost known and owned by all people in Indonesia, as there are woven products that are used in everyday life and are found in rural communities. What is different is the variation, specification and designation of each region. Generally, the basic weaving techniques that are owned by each craftsman are almost identical, but the differentiating points are in terms of the roughness of the webbing, the type of color and the specifications of the motif. Products that can be produced from purun woven handicraft products are household appliances, supporting tools in agricultural activities, to their use as household accessories and decorations.

Kampung purun as the title of Palam sub-district was given in February 2016. Kampung purun is a new initiative with the acronym of (Kelurahan mAju Menggali Potensi UNGgulan dengan Pemberdayaan Usaha keRajinan anyaman purUN). The main objective is to open access to jobs and the sustainability of the peat ecosystem to improve the welfare of the community around the PT Intan mine. Galoeh Cempaka in Palam village. This is done by developing the purun woven creative industry as a superior potential that can become an economic leveraging point.

The products produced by the craftsmen group are also increasingly varied, combined with sasirangan, knickknacks in various forms following the times. This is because of the role of young craftsmen who innovate according to buyer demand. 
The activity of purun craftsmen as an economic activity is the activity of making, utilizing, distributing and utilizing purun plants to become valuable. Based on the classification grouped on the basis of human priorities in meeting the needs of daily life, including secondary activities, namely as activities to process, modify, assemble or make various goods [15].

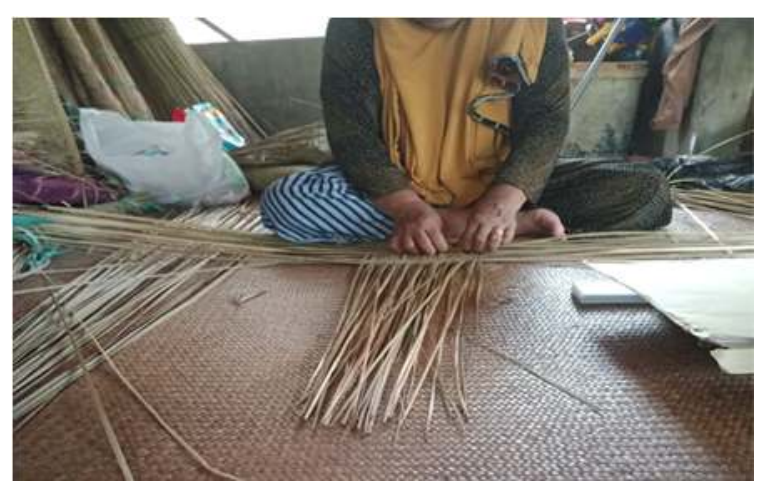

Figure 1 Purun Weaving Stage

Purun weaving is part of secondary activities because it includes processing, converting purun plants which are often referred to as weeds which can disrupt agriculture into useful purun woven crafts. There are variations by being created into woven goods or handicraft products into various forms and useful values compared to purun which are directly sold without being processed or modified or further created such as in secondary activities.

The activity of purun craftsmen is a weaving activity that has been carried out from generation to generation from their parents in ancient times in addition to their livelihoods as farmers. Samuel Soeitoe stated that activities are not just activities, but activities are seen as an effort to achieve or fulfill a need [16]. This is in line with weaving initially only for personal use, along with the ease with which weaving began to change its function to become woven that is sold to the general public in order to fulfill needs. The stages start from lifting the purun, drying, pounding, coloring and finally weaving.

Unlike the case with activities before purun raw materials are processed and created into purun weaving. Purun plants are taken and uprooted from rice fields and seran lakes and then directly sold to craftsmen from outside the region. This shows the primary economic activity, while currently the activities carried out by purun craftsmen are processing, creating and making new forms of purun plants into purun plaits which are of higher value when sold. Purun plants become attractive products in various forms such as bags, wallets, equipment and accessories that combine raw materials with attractive creations.

Craftsmen in purun village have different groups consisting of 4 groups with 2 main groups, namely Galoeh Cempaka and al-firdaus. Each group has its own characteristics seen from the woven product. The variety of weaving forms is more diverse in the Al-firdaus group, following the current trend because it is dominated by mothers and younger adolescents. While the variations and forms of weaving in the Galoeh Cempaka group adjust to the order, usually Galoeh Cempaka becomes primary or original and traditional craftsmen who are not combined with sasirangan cloth or beaded motifs. Each group of craftsmen in terms of techniques has similarities in weaving, the difference is in the variance of the product produced.

Other differences are also in product specifications. Each craftsman is different in terms of smoothness, roughness and thickness of the webbing, coloring and motifs, this is influenced by the production factors used and the process carried out to produce a woven product. Various household utensils, livestock and agricultural equipment, wicker objects or items are also used as home wall decorations and so on [17]. Equipment produced by craftsmen includes mats, baskets or shopping bags, handbags, tissue boxes, drinking bottles, drinking water racks, accessories and other trinkets.

This is a distinctive feature of Galoeh Cempaka being a supplier of original products. Usually, consumers usually buy to be freely created according to the taste of the buyer later. Unlike the case with the Al-firdaus group, they do their own creations and variations to sell, but also accept orders for original or non-creative products.

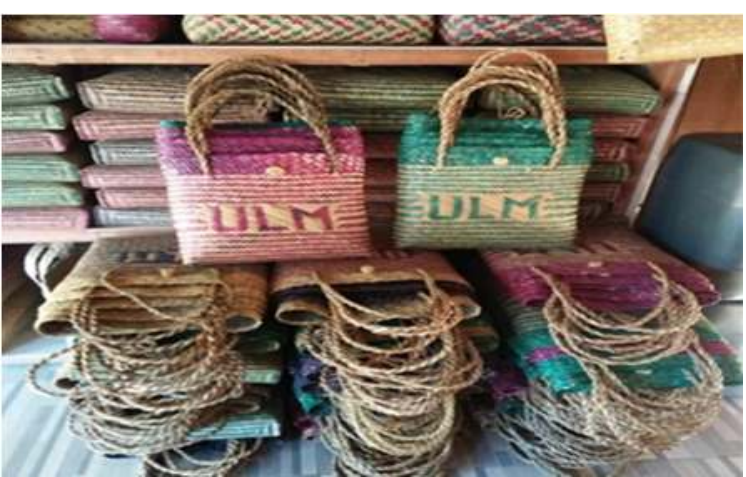

Figure 2 Purun Woven Products

In distribution activities, buyers usually come directly to the craftsmen's house or to the craftsmen's secretariat. The sale and purchase transaction, until the delivery of the purun woven product occurs directly in the sense that there is no intermediary party, because the buyer immediately comes and interacts and carries out buying and selling activities to the craftsmen. In addition, using social media as a media for product promotion such as WhatsApp, Instagram, and Facebook which are owned by craftsmen. In addition, most producers do not directly sell their goods to consumers, namely the existence of distributors. This indicates an indirect distribution. The distributor classification includes; first, traders consisting of wholesalers and retailers who resell the goods. The presence of wholesalers and retailers in the distribution of purun webbing plays an important role, because these distributors buy large quantities of purun woven products. These traders will create or sell back to gift or handicraft shops so that craftsmen do not need to distribute them to other shops. The indirect distribution channels used by the craftsmen are through wholesalers and retailers from handicraft shops or souvenir shops. These 
parties are customers who buy in large quantities from craftsmen.

Second, namely agents, which are distribution channels through distributors called brokers, or sales agents on behalf of producers but do not have rights over the goods. Brokers in the sense here are parties who try to find profit from the existence of woven products by promoting, then if there are buyers who are willing, then buy these woven products for these consumers. This helps the craftsmen to act only as producers without being involved in the process of promotion, dissemination of information and bargaining in buying and selling transactions due to the presence of third parties, namely brokers.

Third, facilitators such as transportation companies, banks, advertising agencies, governments, who only help with the distribution process. There is assistance from agencies such as urban villages, tourism offices, cooperatives and UKM, as well as the Banjarbaru city government through activities and appeals. As revealed by Dhiah Tri Widhiningsih from the Banjarbaru city tourism office, he helps the distribution of products through Banjarbaru city tour packages. Craftsmen take advantage of the role and government policies for the distribution of woven products, including official events, holidays and government office needs. Therefore, it can be interpreted that purun weaving crafts are part of secondary activities because it includes processing, changing purun plants which are often referred to as weeds which can disturb agriculture into useful purun woven crafts. There are variations by being created into woven goods or handicraft products into various forms and useful values compared to purun which are directly sold without being processed or modified or further created such as in secondary activities.

\section{CONCLUSSION}

Activities of purun weaving craftsmen in Palam village, Banjarbaru city are a series of economic activities that process purun plants into woven crafts. Products are not only simple weaving but have been created and distributed both through direct and indirect channels. The role of the souvenir shop owner in the Banjarbaru area, the city government of Banjarbaru and the rapid growth of social media have also contributed so that the woven products of Kampung Purun can penetrate the local, national and international markets. Economic activities by purun craftsmen in Banjarbaru City are a reflection of the community's economic development by utilizing natural resources for sustainable development.

\section{REFERENCES}

[1] I. Ishatono and S. T. Raharjo, Sustainable development goals (SDGs) dan pengentasan kemiskinan. 2016.

[2] C. M. Bah, "Economic Growth, Institutions, and the Natural Resource Curse in Sierra Leone: an Empirical Investigation," vol. 7, no. 5, p. 25, 2016.

[3] J. Jumriani, "Kegiatan Produksi dan Distribusi di Kampung Sasirangan Sebagai Sumber Belajar
IPS,” Jurnal Socius, vol. 7, no. 1, Art. no. 1, 2018, doi: 10.20527/jurnalsocius.v7i1.5280.

[4] A. Horton, "Causal Economics: A new pluralist framework for behavioral economics that advances theoretical and applied foundations," Heliyon, vol. 5, no. 4, p. e01342, Apr. 2019, doi: 10.1016/j.heliyon.2019.e01342.

[5] H. Putro, J. Jumriani, D. Darmawan, and S. Nuryatin, "Social Life of the Community: Perspective of Riverbanks Community in Sungai Jingah, Banjarmasin," The Kalimantan Social Studies Journal, vol. 1, p. 151, Apr. 2020, doi: 10.20527/kss.v1i2.2053.

[6] M. Redzuan and F. Aref, "Constraints and potentials of handicraft industry in underdeveloped region of Malaysia," Afr. J. Bus. Manage., p. 5, 2011.

[7] J. Jumriani, B. Subiyakto, and S. Syaharuddin, "Social Interaction Sasirangan Traders Village in The City of Banjarmasin as a Learning Resources on Social Studies," The Innovation of Social Studies Journal, vol. 1, p. 65, 2019, doi: 10.20527/iis.v1i1.1369.

[8] S. Asikin and M. Thamrin, "Manfaat purun tikus (eleocharis dulcis) pada ekosistem sawah rawa," Jurnal Penelitian dan Pengembangan Pertanian, vol. 31, no. 1, Art. no. 1, 2013, doi: 10.21082/jp3.v31n1.2012.p\%p.

[9] B. Bungin, Metodologi penelitian kualitatif: Aktualisasi metodologis ke arah ragam varian kontemporer. RajaGrafindo Persada, 2019.

[10] N. King, C. Horrocks, and J. Brooks, Interviews in Qualitative Research. SAGE, 2018.

[11] S. Sugiyono, Metode Penelitian Kuantitatif dan Kualitatif dan R\&D. ALFABETA Bandung, 2010.

[12] E. Mulyana, E. Rosana, and D. Paramita, "Analisis Pendapatan Pengrajin Anyaman Tikar Purun di Desa Tanjung Atap Kecamatan Tanjung Batu Kabupaten Ogan Ilir," Prosiding SEMNASTAN, vol. 0, no. 0, Art. no. 0, 2018.

[13] E. W. Abbas and J. Jumriani, "Culinary Identification in the Banua Anyar Culinary Tourism Area; a Contribution for Tourism in Banjarmasin City," The Innovation of Social Studies Journal, vol. 2, no. 1, Art. no. 1, 2020, doi: 10.20527/iis.v2i1.2309.

[14] M. Mustafa, "Potential of Sustaining Handicrafts as a Tourism Product in Jordan," International Journal of Business and Social Science, vol. 2, pp. 145-152, Jan. 2011.

[15] A. Heryawan, A. Fauzi, and A. Hidayat, "Analisis Ekonomi dan Kebijakan Sumber Daya Alam Provinsi Jawa Barat," Journal of Agriculture, Resource and Environmental Economics, vol. 1, no. 2, Art. no. 2, 2014. 
[16] S. Roimah, "Aktivitas Dakwah IPNU-IPPNU di Kecamatan Sukoharjo Kabupaten Wonosobo Periode 2012-2014," Skripsi, UIN Walisongo, Semarang, 2014.

[17] Kamsinah, "Kehidupan Ekonomi Para Pengrajin Anyaman di Desa Candi Laras Selatan Kabupaten Tapin tahun 1984-2008," Skripsi, Universitas Lambung Mangkurat, Banjarmasin, 2010. 